\title{
ANALISIS KEMAMPUAN PEMAHAMAN MATEMATIK SISWA PADA MATERI SEGIEMPAT
}

\author{
Aat Atikah $^{1}$, Euis Eti Rohaeti ${ }^{2}$ M. Afrilianto $^{3}$ \\ 1,2,3IKIP Siliwangi, Jl. Terusan Jendral Sudirman Cimahi 40526 \\ ${ }^{1}$ hanifahusna09@gmail.com, ${ }^{2}$ e2rht@ikipsiliwangi.ac.id, ${ }^{3}$ muhammadafrilianto@ikipsiliwangi.ac.id,
}

\begin{abstract}
This study aims to determine the ability of mathematical understanding of class VII students on the material wake flat. The type of research used is a qualitative descriptive research. The subjects of this study consisted of 5 students selected at random. The data collected in the form of written test results as much as 5 points about the ability of students' mathematical understanding. The test results were analyzed according to the students' mathematical comprehension indicator. Data analysis is done to analyze the extent of students' mathematical understanding ability. Based on the result of research that students mathematical understanding ability still not enough in each indicator. From this research can be concluded that students mathematical understanding ability in VII grade in finished the matter of getting up flat is still low.
\end{abstract}

Keywords: Mathematical Understanding, Build Flat

\begin{abstract}
Abstrak
Tujuanpenelitian ini adalah untuk mengetahui Kemampuan Pemahaman Matematik Siswa SMP dalam Pembelajaran Matematika. Penelitian ini menggunakan pendekatan deskriptif kualitatif.Penelitian ini dilaksanakan di SMP Negeri 2 Cibuaya dengan subjek siswa kelas VII SMP Negeri 2 Cibuaya yang berjumlah 5 siswa. Jenis tes pada penelitian ini adalah tes uraian. Tes di analisis sesuai indikator kemampuan pemahaman matematik siswa. Analisis data yang dilakukan bertujuan untuk menganalisis sejauhmana kemampuan pemahaman matematik siswa. Berdasarkan hasil penelitian bahwa kemampuan pemahaman matematik siswa masih kurang di setiap indikatorrya. Dari penelitian tersebut dapat disimpulkan bahwa kemampuan pemahaman matematik siswa kelas VII dalam menyelesaikan soal bangun datar masih rendah.
\end{abstract}

Kata Kunci: PemahamanMatematik, Segiempat

How to cite: Atikah, A., Rohaeti, E.E., Afrilianto, M.(2018). Analisis Kemampuan Pemahaman Matematik Siswa pada Materi Segiempat. JPMI - Jurnal Pembelajaran Matematika Inovatif, 1 (4), 735-742.

\section{PENDAHULUAN}

Pendidikan merupakan salah satu alatuntuk meningkatkan taraf hidup bangsa. Pada dasarnya pendidikan merupakan sebuah upaya untuk meningkatkan kualitas sumber daya manusia (SDM). Matematika merupakan salah satu ilmu yang sangat penting dalam dunia pendidikan. Salah satu faktor penting dalam pembelajaran matematika saat ini adalah pentingnya pengembangan kemampuan pemahaman matematis siswa.

Masalah utama yang sering dihadapi pada pelajaran matematika adalah rendahnya kemampuan pemahaman konsep siswa. Sehingga sebagian besar siswa tampak mengikuti dengan baik setiap penjelasan atau informasi dari guru, siswa sangat jarang mengajukan pertanyaan sehingga guru asyik sendiri menjelaskan apa yang telah disampaikannya (Hidayat 
\& Sumarmo, 2013; Muchlis, Komara, Kartiwi, Nurhayati, Hendriana, \& Hidayat, 2018; Rahmi, Nadia, Hasibah, \& Hidayat, 2017; Wahyu, 2014; Zakiah, Saomi, Syara, Hidayat, \& Hendriana, 2018).

Menurut (Setiawan, Bharata, \& Caswita, 2017)pemahaman merupakan aspek fundamental dalam pembelajaran, sehingga model pembelajaran harus menyertakan hal pokok dari pemahaman. Hal-hal pokok dari pemahaman untuk suatu objek meliputi tentang objek itu sendiri, relasi dengan objek lain yang sejenis, relasi dengan objek lain yang tidak sejenis.

Skemp (Sumarmo, 2017) menyatakan bahwa terdapat dua jenis kemampuan pemahaman yaitu: a) pemahaman instrumental yang artinya hafal sesuatu secara terpisah atau dapat menerapkan sesuatu pada perhitungan rutin/sederhana, mengerjakan sesuatu secara algoritmik. Pada pemahaman ini siswa hanya menghafal rumus dan mengikuti urutan pengerjaan dan algoritma saja; dan b) pemahaman relasional yang berarti dapat melakukan perhitungan secara bermakna pada permasalahan-permasalahan yang lebih luas, termuat skema atau struktur yang dapat digunakan pada penyelesaian yang memuat masalah yang lebih luas, dapat mengaitkan suatu konsep/prinsip lainnya dan sifat pemakaiannya lebih bermakna.

Permasalahan pada kemampuan pemahaman metematis banyak ditemukan sekolahmenengah pertama. Siswa cenderung hafalan untuk menyelesaikan soal. Depdiknas(Sumarmo, dkk 2017) merinci kemampuan pemahaman sebagai berikut: a) menyatakan ulang sebuah konsep; b) mengklasifikasikan objek-objek menurut sifat-sifat tertentu sesuai dengan konsepnya; c) memberi contoh dan bukan contoh dari konsep; d) menyajikan konsep dalam berbagai bentuk representasi matematis; e) mengembangkan syarat perlu atau syarat cukup suatu konsep; f) menggunakan,memanfaatkan, dan memilih prosedur atau operasi tertentu; g) mengaplikasikan konsep atau algoritma dalam pemecahan masalah matematis.Dari beberapa pendapat diatas dapat disimpulkan bahwa kemampuan pemahaman matematis adalah suatu kemampuan siswauntukmencari informasi atau materi, rumus dan konsep matematika serta menerapkanna dalam suatu kasus yang dihadapi sehingga siswa dapat menyelesaikan kasus tersebut.

Fakta yang ditemui oleh peneliti yaitu ketika melakukan wawancara baik dengan guru mata pelajaran ataupun dengan siswa ternyata ketika siswa diberi materi oleh gurunya, mereka tidak mengerti dengan apa yang disampaikanoleh guru, selain itu dilihat dari cara siswa menjawab soal yang diberikan kebanyakan siswa menjawab pertanyaan tidak sesuai dengan apa yang diinginkan pertanyaan tersebut.

Oleh karena itu, peneliti melakukan observasi bertujuan untuk mengetahui sejauh mana kemampuan pemahaman matematik siswa serta dengan siswa dapat memahami suatu materi atau kasus siswa dapat menyelesaikan kasus tersebut dengan lebih terarah. Dengan diadakan penelitian ini siswa dapat lebih memahami materi dan kasus serta konsep matematika dan juga pendidik dapat mengembangkan pembelajaran agar kedepan siswa dapat mudah memahami materi yang disampaikan oleh pendidik.

\section{METODE}

Penelitian ini merupakan penelitian deskriptif dengan menggunakan pendekatan kualitatif. (Haji, 2014) mengatakan bahwa penelitian deskriptif bertujuan untuk menggambarkan secara tepat sifat-sifat suatu individu, keadaan gejala atau kelompok tertentu. Sementaraitu, Moleong (Pratiwi, 2016) mengungkapkan metode penelitian kualitatif sebagai prosedur 
penelitian yang menghasilkan data deskripstif berupa kata-kata tertulis atau lisan dari orangorangdan perilaku yang dapat diamati.

Penelitian ini ditulis untuk menganalisis dan mendeskripsikan kemampuan pemahaman matematik siswa kelas VII dalam materi Segi empat yang berpedoman pada terpenuhi atau tidaknya indikator-indikator pemahaman matematik. Subjek penelitian ini adalah 5 siswa kelas VII yang diambil secara proposive sampling. Teknik pengambilan data pada penelitian ini dilakukan dengan menggunakan tes dalam bentuk uraian yang dibuat oleh peneliti.

Ruseffendi (2010) tes uraian sering juga disebut tes tipe subjektif, sebab skor pekerjaan seseorang dipengaruhi oleh penilai: latar belakang penile, kemampuan memahami dari penilai, kondisi penilai, dan sebagainya. Prosedur dalam penelitian ini terdiri dari 3 tahap yaitu: 1) tahap persiapan, dalam tahap persiapan peneliti melakukan beberapa hal diantaranya melakukan pra riset kepada sampel (siswa), menyiapkan instrumen soal kemampuan pemahaman. 2) tahap pelaksanaan, dalam tahap ini peneliti melakukan pretest kepada subjek dan menganalisa hasil jawaban. 3) tahap akhir, dalam tahap akhir peneliti menganalisis data, mendeskripsikan hasil penelitian dan menyusun laporan penelitian.

Instrumen utama adalah peneliti. Peneliti merupakan perencana, pelaksana pengumpulan data, analis, penafsir data, dan menjadi pelapor hasil penelitiannya. Instrumen pendukung pada penelitian ini berupa tes. Tes yang digunakan pada penelitian ini adalah tes kemampuan pemahaman matematik yang terdiri dari 5 soal berupa soal-soal dengan materi segiempat. Tes yang digunakan telah dikonsultasikan kepada pembimbing. Selainitu, rubrik penilaian tes disusun berdasarkan indikator pemahaman matematik yang telah ditentukan.

Berdasarkan rubrik tersebut peneliti dapat menentukan apakah siswa meenuhi masing-masing indikator pemahaman atau tidak. Data yang diperoleh kemudian disesuaikan dengan rubrik penilaian tes. Selanjutnya diolah dengan menentukan presentase keterpenuhan masingmasing indikator pemahaman matematik. Kemampuan pemahaman matematik siswa dikatakan tinggi apabila persentase keterpenuhan indikator pemahaman matematik minimal $75 \%$ siswa pada setiap soal.

\section{HASIL DAN PEMBAHASAN}

\section{Hasil}

Penelitian ini dilaksanakan pada salah satu kelas VII disalah satu SMP negeri yang ada diKarawang .Sesuai dengan pertanyaan penelitian yang telah dikemukakan sebelumnya maka untuk menjawab pertanyaan penelitian tersebut dilakukan pembahasan dan analisis jawaban untuk mengungkap kemampuan pemahaman matematik yang dilakukan siswa dari setiap jawaban soal tesyang dijadikan sampel penelitian. Mendeskripsikan pemahaman matematik siswa dalam menyelesaikan soal pada materi segi empat pada tiap soal.

Sampel penelitian berjumlah 5 siswa. Data hasil penelitian ini yaitu berupa hasil penskoran kemampuan pemahaman matematik siswa yang pengumpulan datanya menggunakan instrumen berupa soal tes uraian sebanyak 4 soal. Penilaian atau penskoran dalam penelitian (Setiawan et al., 2017) kemampuan pemahaman berpedoman padapenskoran menurut Holistic scoring rubrics dari Utari (dalam Hardiyanti, 2015:20) seperti tertera pada tabel berikut. 
Tabel 1. Penskoran Pemahaman

\begin{tabular}{|c|c|c|}
\hline $\begin{array}{c}\text { Tingkat } \\
\text { Pemahaman }\end{array}$ & Kriteria & skor \\
\hline Tidak Paham & Jawaban hanya mengulang pertanyaan & 0 \\
\hline Miskonsepsi & $\begin{array}{l}\text { Jawaban menunjukan salah paham yang berdasar } \\
\text { tentang konsep yang dipelajari }\end{array}$ & 1 \\
\hline $\begin{array}{c}\text { Miskonsepsi } \\
\text { Sebagian }\end{array}$ & $\begin{array}{l}\text { Jawaban memberikan sebagian informasi yang } \\
\text { benar tapi menunjukan adanya kesalahan konsep } \\
\text { dalam menjelaskan }\end{array}$ & 2 \\
\hline Paham Sebagian & $\begin{array}{l}\text { Jawaban benar dan mengandung paling sedikit } \\
\text { konsep ilmiah serta tidak mengandung satu } \\
\text { kesalahan konsep }\end{array}$ & 3 \\
\hline Paham Seluruhnya & $\begin{array}{l}\text { Jawaban benar dan mengandung seluruh konsep } \\
\text { ilmiah }\end{array}$ & 4 \\
\hline
\end{tabular}

Hasil dari penelitian ini menggunakan hasil penskoran berdasarkan hasil soal tes uraian yang di sajikan berupa data. Berikut adalah data dari hasil penelitian:

Tabel 2. Data Hasil Penelitian

\begin{tabular}{cccccccc}
\hline Subjek & \multicolumn{5}{c}{ SOAL } & Jumlah & $\begin{array}{c}\text { Prosentase } \\
\text { skor }\end{array}$ \\
\cline { 2 - 6 } & 1 & 2 & 3 & 4 & 5 & \multicolumn{1}{c}{ ) } \\
\hline 1 & 2 & 4 & 3 & 3 & 2 & 14 & 70 \\
2 & 1 & 3 & 2 & 4 & 0 & 10 & 50 \\
3 & 1 & 4 & 4 & 3 & 0 & 12 & 60 \\
4 & 1 & 2 & 1 & 3 & 2 & 9 & 45 \\
5 & 1 & 2 & 1 & 2 & 0 & 6 & 3 \\
\hline Presentase/soal & $\mathbf{3 0}$ & $\mathbf{7 5}$ & $\mathbf{5 5}$ & $\mathbf{7 5}$ & $\mathbf{2 0}$ & Rata-rata & $\mathbf{5 3} \%$ \\
\hline
\end{tabular}

Dari data tersebut dapat diketahui ada beberapa soal yang tidak mencapai indikator. Berikut data soal yang tidak mencapai target indikator:

Tabel 3. Prosentase Pencapaian Indikator

\begin{tabular}{|c|c|c|c|}
\hline Indikator & $\begin{array}{l}\text { Mendefinisikan } \\
\text { konsep secara } \\
\text { verbal dan tulisan }\end{array}$ & $\begin{array}{l}\text { Mengidentifikasi } \\
\text { sifat-sifat suatu } \\
\text { konsep }\end{array}$ & $\begin{array}{c}\text { Menggunakan } \\
\text { model diagram dan } \\
\text { simbol-simbol } \\
\text { untuk } \\
\text { mempresentasikan } \\
\text { suatu konsep }\end{array}$ \\
\hline SMI & 4 & 4 & 4 \\
\hline Rata-rata & 1.2 & 2.2 & 0.8 \\
\hline Presentase & $30 \%$ & $55 \%$ & $20 \%$ \\
\hline
\end{tabular}

Dari tabel dapat kita lihat bahwa kemampuan pemahaman matematis siswa masih kurang di setiap indikatornya. Indikator pertama merupakan mendefinisikan konsep secara verbal dari hasil analisis siswa kemampuan pemahaman siswa cukup. Indikator kedua merupakan mengidentifikasi sifat-sifat suatu konsep dari hasil analisi siswa kemampuan pemahaman 
sudah cukup. Indikator ketiga merupakan Menggunakan model diagram dan simbol-simbol untuk mempresentasikan suatu konsep dari hasil analisis siswa kemampuan pemahaman matematik siswa masih kurang.

\section{Pembahasan}

Dari tabel data hasil penelitian dapat dilihat bahwa rata-rata presentase kemampuan pemahaman matematik siswa dalam menyelesaikan soal yang diberikan oleh peneliti yang berjumlah 5 butir soal yaitu 53\%. Berdasarkan hasil tersebut, kemampuan pemahaman matematik yang dimiliki oleh siswa masih terbilang rendah. Berikut adalah pembahasan soal yang masih belum mencapai angka persentase yang diinginkan peneliti.

Pada soal no 1, yaitu yani memiliki taman dengan luas $32 \mathrm{~m}^{2}$. Jika panjang taman $8 \mathrm{~m}$. berapakah lebar taman tersebut?. Dari hasil analisis ternyata ada beberapa siswa yang tidak mengerti apa yang dimaksudkan soal tersebut.

\section{$40 \mathrm{~cm}^{2}+160 \mathrm{~cm}$ $=260$}

Gambar 1. Jawaban siswa soal no 1

\section{Soal No 3}

Sebuah taplak meja berbentuk persegi panjang dengan ukuran panjang $90 \mathrm{~cm}$ dan lebar $60 \mathrm{~cm}$ berapakah keliling dang luas persegi panjang tersebut.

Pada soal no 3, siswa diminta untuk menghitung keliling danluasbangun datar tersebut. Dari hasil analisis ada 1 siswa yang mendapat nilai 4 (20\%), 1 siswa mendapat nilai $3(20 \%), 1$ siswa mendapat nilai $2(20 \%)$ dan 2 siswa mendapat nilai 1 (40\%). Jawaban siswa seperti gambar berikut:

\section{Felling telapak tSB : $: 2 \times P+L: 150$$$
\text { DIK }=2 \times 90+60=240 \mathrm{~cm}
$$

Gambar 2. Jawaban siswa soal no 3

\section{Soal No 5}

Halaman rumah berbentuk persegi panjang berukuran panjang $90 \mathrm{~m}$ danlebar $65 \mathrm{~m}$. Di sekeliling halaman itu akan dipasang pagar dengan biaya Rp. 135.000,00 permeter. Berapa biaya yang di perlukan untuk pemasangan pagar tersebut? 
Dan pada soal no 5, siswa di minta untuk menentukan panjang sisi dari suatu laying-layang. Dari hasil analisis ada 2 siswa yang mendapat nilai $2(40 \%)$ dan 3 siswa mendapat nilai 0 $(60 \%)$. Jawaban siswa hanya mengulang pertanyaan seperti gambar berikut:

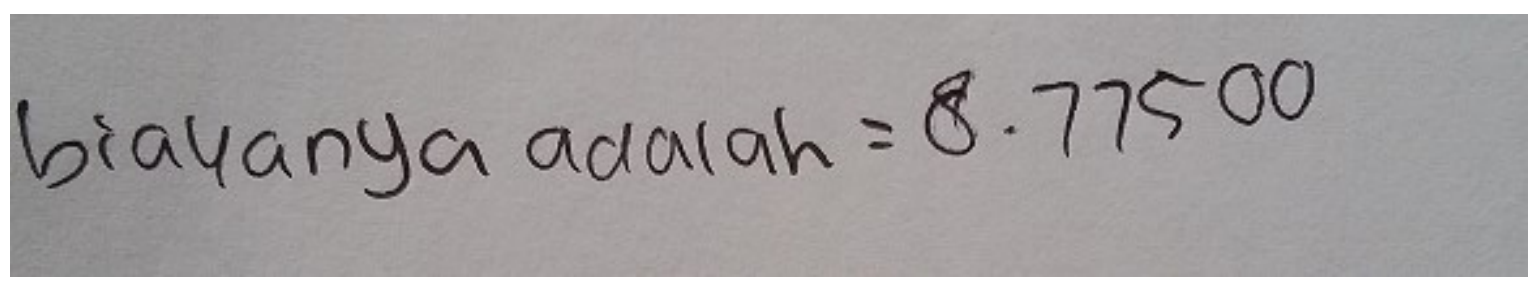

Gambar 3. Jawaban siswa soal no 5

Dari pembahasan diatas bahwa menggunakan kemampuan pemahaman matematik dapat meningkatkan prestas siswa dikelas.Menurut (Putri, Nursyahban, Kadarisma, \& Rohaeti, 2018) bahwa pembelajaran menggunakan kemampuan pemahaman matematik bukan hanya sebagai hafalan, siswa juga memiliki pondasi atau dasar yang kokoh dalam pembelajaran matematika.(Aminudin, 2013) mengemukakan bahwa salah satu kecakapan ( proficiency) dalam matematika yang penting dimiliki oleh siswa adalah pemahaman konsep ( conceptual understanding).

\section{KESIMPULAN}

Berdasarkan hasil analisis dan pembahasan, maka dapat disimpulkan kemampuan pemahaman matematik siswakelas VII dalam menyelesaikan soal bangun datar masih rendah. Hal tersebut ditunjukkan dengan hasil tes kemampuan pemahaman matematik siswa tidak maksimal.Siswa mengalami kesulitan dalam memahami soal karena siswa masih bingung dan belum mampu memaknai kalimat yang disajikan. Siswa juga kebingungan dalam memilih konsep yang harus digunakan dalam menyelesaikan soal. Meskipun siswa belum memperoleh jawaban yang tepat, tetapi siswa telah berusaha untuk menjawab soal dengan maksimal.

Hasil penelitian ini diharapkan dapat memberikan informasi kepada pihak sekolah mengenai kemampuan pemahaman matematis siswa. Mengingat pentingnya pemahaman matematik dan fakta mengenai kemampuan pemahaman matematik siswa, diharapkan guru mampu merancang konsep kegiatan pembelajaran yang dapat meningkatkan kemampuan pemahaman matematik siswa.

\section{DAFTAR PUSTAKA}

Aminudin, R. (2013). Penerapan Metode Penemuan Terbimbing Untuk Meningkatkan Pemahaman Siswa Kelas VII SMP Negeri 6 Palu Pada Materi Hubungan Sudut-Dalam Dan Sudut-Luar Segitiga. Jurnal Elektronik Pendidikan Matematika Tadulako, 1(1).

\section{Aripin, U. (2016). MENINGKATKAN KEMAMPUAN PEMAHAMAN MATEMATIK SISWA SMP MELALUI PENDEKATAN PEMBELAJARAN BERBASIS MASALAH. P2M STKIP Siliwangi, 2(1), 120-127.}

Haji, S. (2014). STRATEGI THINK-TALK-WRITE UNTUK MENINGKATKAN KEMAMPUAN REPRESENTASI MATEMATIK, Infinity. 
Hidayat, W., \& Sumarmo, U. (2013). Kemampuan Komunikasi dan Berpikir Logis Matematika serta Kemandirian Belajar. dalam Jurnal Delta-fi, 2(1).

Muchlis, A., Komara, E. S., Kartiwi, W., Nurhayati, N., Hendriana, H., \& Hidayat, W. (2018). MENINGKATKAN KONEKSI MATEMATIS SISWA SMP MELALUI PENDEKATAN OPEN-ENDED DENGAN SETTING KOOPERATIF TIPE NHT. KALAMATIKA Jurnal Pendidikan Matematika, 3(1), 81-92.

Putri, N. R., Nursyahban, E. A., Kadarisma, G., \& Rohaeti, E. E. (2018). ANALISIS KEMAMPUAN PEMAHAMAN MATEMATIK SISWA SMP PADA MATERI SEGITIGA DAN SEGIEMPAT. JPMI (Jurnal Pembelajaran Matematika Inovatif), 1(2), 157-170.

Rahmi, S., Nadia, R., Hasibah, B., \& Hidayat, W. (2017). The Relation between Self-Efficacy toward Math with the Math Communication Competence. Infinity Journal, 6(2), 177182.

Setiawan, W., Bharata, H., \& Caswita, C. (2017). Pengaruh Discovery Learning Terhadap Pemahaman Konsep Matematis Siswa. Jurnal Pendidikan Matematika Unila, 5(9).

Wahyu, H. (2014). THE IMPLEMENTATION OF MEAs INSTRUCTION TO STUDENTS'MATHEMATICS PROBLEM SOLVING AND CONNECTING ABILITY. In Proceeding of International Conference On Research, Implementation And Education Of Mathematics And Sciences 2014. Yogyakarta State University.

Zakiah, L., Saomi, A. S. N., Syara, R., Hidayat, W., \& Hendriana, H. (2018). THE EFFICIENCY OF USING EDUCATION VIDEOS ON THE LINEAR PROGRAM MATERIAL AS OBSERVED IN VOCATIONAL HIGH SCHOOL STUDENTS'MATHEMATICAL COMMUNICATION ABILITY.Journal Of Educational Experts (JEE), 1(1), 11-18. 
742 Atikah, Rohaeti, \& Afrilianto, Analisis Kemampuan Pemahaman Matematik Siswa ... 